\title{
Salves and silver bullets
}

Published at www.cmaj.ca on Mar. 24

I t's called black salve and according to dozens of websites, it will cure cancer (skin, prostate, colon and breast), alleviate yeast infections, remove plaque and even eradicate gum disease.

Marketed under such monikers as Grandma's Black Salve, American Native Black Salve, Balm of Gilead or Compound $\mathrm{X}$, it has testimonials galore:

'In the 1960's (Howard McCreary) was diagnosed as having stomach cancer," says one website. "He took an oral dose of Compound $\mathrm{X}$ the night before his scheduled surgery.... On the 5th day Howard said he passed a large quantity of black, vile smelling feces, apparently the growth itself. When the doctors took x-rays ... the cancerous growth was gone."

"About two years ago my Brotherin-law had a cancerous mole on his forehead," says another. "My Brotherin-law ... used Black Salve that I had given him. He said that he experienced a lot of pain with it but he tolerated it as he knew it was working."

Adam Zimmerman, competition law officer with the Competition Bureau of Canada, which regulates false and misleading advertising, says there's a good reason the user experienced a lot of pain. "It actually burns the skin. So you end up with scars and burn tissue. Black salve is outright illegal in the US [United States] and hasn't been approved for sale in Canada," although some websites claim otherwise.

It's also an excellent example of what are commonly called quack medicines - salves and tonics, pills and potions, gadgets and cures that promise wondrous benefits.

"Quackery has always been with us," says Jim Connor, professor of medical humanities and history of medicine at Memorial University in St. John's, Newfoundland and Labrador. "Maybe the common factor is quacks

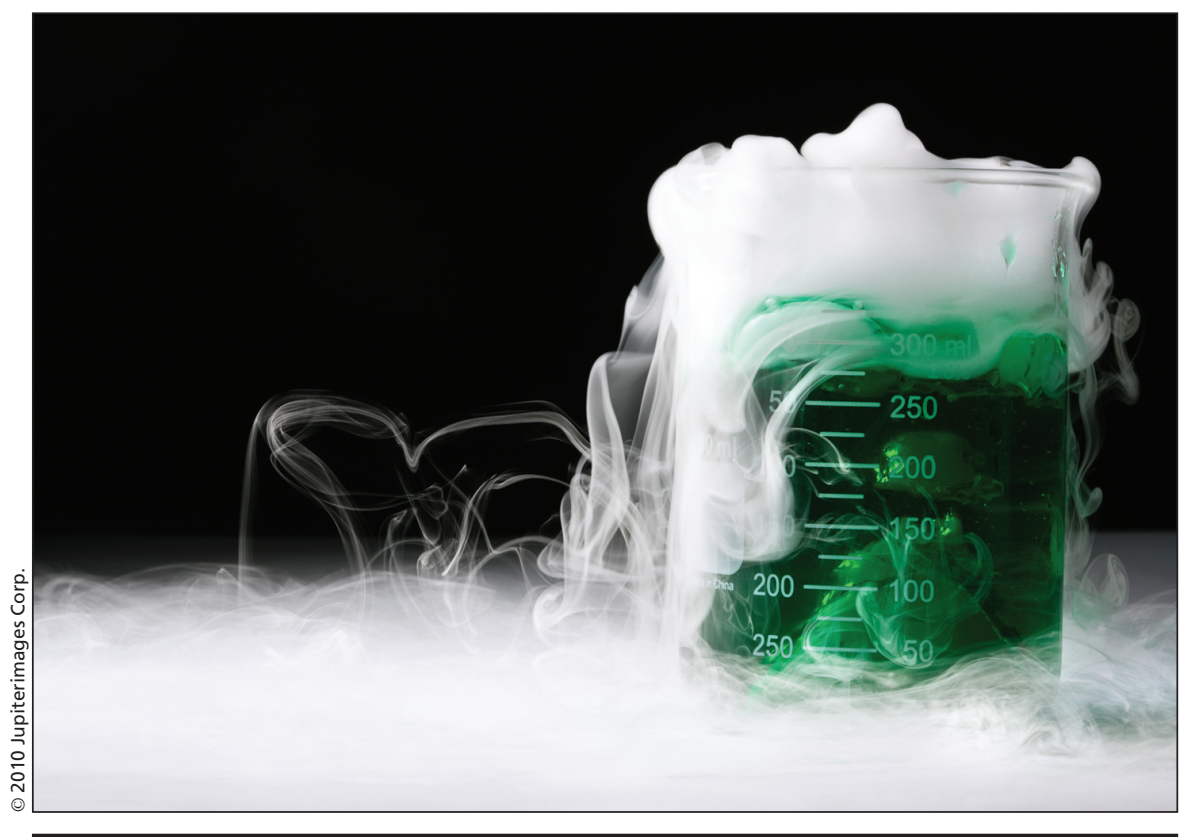

Potions and pills promising wondrous benefits have "always been with us," says Jim Connor, professor of medical humanities and history of medicine at Memorial University in St. John's, Newfoundland and Labrador.

certainly directly respond to the marketplace. They may take on different colours and hues and shapes and sizes over the years, but clearly they seem to be able to exploit the public, or a gullible public, or sometimes a very willing public, with respect to a particular in-vogue ailment or problem or market niche."

There's probably less quackery than in the past due to stronger government regulation and a medical establishment that quacks find harder to duck, Connor says. "The quack has to use different media and you have to pay for that media and that means that they leave a paper trail or some kind of record. If you go back to the 19th century, I could just get on my horse and wagon and go around villages and set up my stall and sell my coloured water for everything that ails you and move on. So I would be very mobile and it would be very difficult for the long arm of the law or the medical law to catch up with me."

But scammers can now tap a much larger audience, he adds. "The charac- teristic 19 th-century quack or charlatan would maybe go to a fair and try to drum up business with a crowd of maybe 10 or 20 people around you. But if you put something on the Internet, who knows how many millions of people you could hit in a millisecond."

Hucksters may also be more adept at "sensing where the gaps are" in the market, Connor adds. "Obesity is clearly a market. It's also perhaps a field where, I won't say biomedicine has failed, but there is a gap there between what organized medicine might be able to do and the quack can slip through the cracks and appeal directly to the customer."

Zimmerman says scammers often seek to drive a wedge between patients and doctors. "The scammers are constantly preying on the consumer's sense of fear. The basic trick is to say, 'I'm the only guy with the cure for this.' When you're at the point when you're saying, 'Look, medical science isn't doing anything for me,' that's when you take the bait." 
The silver bullets include weightloss gimmicks and cures for life-threatening conditions or diseases, he adds.

It was ever thus.

The Museum of Health Care in Kingston, Ontario, houses more than 30 000 medical artifacts from the 18th century onward. That includes surgical tools, laboratory instruments and medical potions, including a large collection of bottles of the enduringly popular, "Lydia Pinkham's Vegetable Compound," a cure-all for "female complaints."

"It's difficult to judge the effectiveness of these things because it's all in the eyes of the beholder," says curator Paul Robertson. "If it's effective for you, then it's effective therapy. It's medicine. For many people who relied on them they often were effective in that they felt better."

"For example, here at the museum, we have cholera medication which, if you analyze it, it has nothing to do with battling cholera but it probably took your mind off it," he adds. "Oftentimes, you felt better because many of these patented medicines from the 19th and early 20th centuries had a heavy alcohol base and often had an opiate base as well - morphine, cocaine, that kind of thing were all standard ingredients for the time. It wasn't a cure, even though perhaps they purported to be cures in the early days. As regulations changed, of course they had to claw back on that, tone down the rhetoric. But I think it was more the fact that people felt better."

Many of those therapies were more affordable and accessible in an era when doctors didn't necessarily have as lofty a status and weren't as accessible.

"You didn't run to the doctor or a hospital the way we would now," Robertson says. "Hospitals were generally places people went to die. Drugs were also aimed at a lower income population because they didn't have access to some of the other treatments that wealthy people did. You had to be fairly wealthy to go to the spas."

Holistic medicine claims some benefits that are not clinically verified but that doesn't mean some of those therapies aren't helpful, he adds. "Echinacea for colds, for example. The clinical studies indicate that maybe it isn't as effective as you think. But who knows? I know I take it, for what it's worth."

Connor notes that acupuncture, homeopathy and various spa treatments were deemed quackery for decades but are now often considered "complimentary and alternative medicine. I think a significant portion of mainstream medicine would now view that as being a useful adjunct to regular care. So that's not a question of tightening up laws. I think it's a question of redefining how a therapy or a medical system is interpreted."

It's easy to "demonize" therapies, says Jackie Duffin, professor of medicine at Queen's University in Kingston. “One man's quackery is another man's mainstream medicine. It's a term that gets bandied around all the time, but it's the unlicensed and unregulated practise of health care."

That distinction was meaningless in an era in which everyone was prescribing alcohol, opium and other "drugs we consider poison," she adds. "The whole tilting towards improving medicine means that we should be prepared to view our current medicine as wrong, someday. So the word quack is a pejorative. ... Things that get labelled quackery are not only fraudulent money-making. There are wise women, herbalists who get called quacks who really believe in their remedies and don't make lots of money out of it."

Such remedies only became "quackery" when doctors were given regulatory authority to essentially oversee the medical profession, Duffin says. "Once one kind of medicine triumphed and became the main medicine, then all others became alternative. Once doctors developed their own colleges, they became self-governing. Doctors determine who gets a licence. Doctors determine who should be disciplined. It's an amazing privilege that is accorded to them in modern societies."

Duffin argues, though, that it's important for physicians to keep apprised of what alternative therapies their patients are utilizing and to that end, notes that medical students at Queen's are now being taught to approach patients with "very neutral, nonjudgmental questions. ... If we reveal our hostility towards it, in the way we question them, they're not going to tell us."

History also shows that some legitimate therapies are appropriated by quacks just to hustle a buck, Robertson says. "Some electrotherapy was, I believe, legitimate but at one point it got a bad rep in the early to mid-20th century. One of the things that gave it that bad rep were these electrical belts which men and women could use to electrically stimulate digestion. But it was largely marketed to men as the Viagra of today. There were special loops that would attach around the genitals to give a little bit of an electrical stimulation. That was supposed to help with so-called men's weaknesses."

Erectile dysfunction has now gone mainstream, Connor notes. "I don't know about you, but I certainly get plenty of email suggesting all the things that are wrong with me and all of the things that will fix me up. Is that quackery? What about Viagra and Cialis? The largest pharmaceutical corporation on the planet is selling a drug for erectile dysfunction. At one time that might have been considered quackery."

The line between mainstream medicine and quackery can be blurry, Robertson says, citing energy drinks as an example. "This is really a modern version of the patent drugs of years ago. It's partly the language. It cloaks it in a quasi-medical way and it's building energy, it's revitalizing. This is kind of a neat, modern retread of an old idea."

Quackery is forever, Zimmerman muses. "If there is one thing quackery needs to proliferate, it would be someone who is willing to part with their money for a miracle cure. And there is never any shortage of that." - Becky Rynor, Ottawa, Ont.

DOI:10.1503/cmaj.109-3215 